\title{
Obesity and Diabetes Mellitus with Striking Congenital Hyperplasia of the Islets of Langerhans in Spiny Mice (Acomys Cahirinus)*
}

\author{
I. Histological findings and preliminary metabolic observations
}

\author{
By \\ Alain E. Gonet, Werner Stauffacher, Raymond Pictet and Albert E. Renold \\ with the technical assistance of JANINE MoUgIN \\ From the Institut de Biochimie Clinique, Université de Genève, Genève, Suisse
}

Received January 3, 1966

Summary. Spiny mice (Acomys) are a group of small rodents indigenous to the Eastern Mediterranean and Africa. The Acomys Cahirinus strain reported on here is indigenous to Israel. The strain is characterized by striking and congenital hyperplasia of the islets of Langerhans, primarily of the beta cells. The endocrine tissue contributes up to 15 per cent of the pancreatic mass in adults, up to 25 per cent in the newborn. Pancreatic insulin content may be as high as 100 units per gram wet weight. When fed ad libitum in the laboratory approximately one-half of the animals become obese, while approximately 15 per cent develop a diabetes mellitus-like state with moderate hyperglycemia, glucosuria, and, less frequently, ketonuria accompanied by weight loss and, ultimately, death. The development of the diabetic state is associated with degranulation and, later, striking glycogenic degeneration of the beta cells of the islets of Langerhans. There is also severe glycogenic nephrosis and myocardosis and preliminary observations suggest the presence of thickening of the capillary basement membrane of the renal glomeruli and in the endocrine pancreas. The interrelationships of hyperplasia of the islets of Langerhans, obesity, and diabetes mellitus are as yet to be established, as are the genetic characteristics of each of these entities. An important area of potential usefulness derives from the degree of the hyperplasia of the endocrine tissue, since this should greatly facilitate ultrastructural studies, microdissection and transplantation, as well as organ or tissue culture work. Also, the association of anomalies observed in these spiny mice may, through their systematic study, provide clues for the study of the association of diabetes and obesity with relative hyperinsulinism in man.

Résumé. Les souris à piquants (Acomys) sont des petits rongeurs indigènes de la Méditerranée orientale et de l'Afrique. La souche d'Acomys Cahirinus que nous décrivons ici provient d'Israël. Cette souche est caractérisée par une hyperplasie extrême et congénitale des ilots de Langerhans, surtout des cellules bêta. Le tissu endocrine constitue jusqu'à $15 \%$ de la masse pancréatique des animaux adultes, et jusqu'à $25 \%$ pour les nouveaunés. Les taux d'insuline pancréatique s'élèvent jusqu'à 100 unités par gramme. Lorsque ces souris sont nourries ad libitum dans le laboratoire, à peu près la moitié d'entre elles

* This work was supported by the Fonds National Suisse de la Recherche Scientifique (Grant No. 3244), Berne, Switzerland, and by grants-in-aid from Diabetes Foundation, Inc., Boston, Massachusetts and the Fondation Emil Barell pour le Développement de la Recherche Médicoscientifique, Basel, Switzerland. deviennent obèses, et l'on voit apparaître chez $15 \%$ environ un état diabétique comportant une hyperglycémie modérée, de la glucosurie et moins souvent, de la cétonurie avec perte de poids aboutissant à la mort. L'apparition du diabète est associée à une dégranulation d'abord, puis à une dégénérescence glycogénique des cellules bêta des îlots de Langerhans. On observe également une néphrose glycogénique sévère ainsi qu'une myocardose glycogénique. Des observations encore préliminaires ont permis de constater la présence d'un épaississement des membranes basales des capillaires des glomérules du rein et de celles du pancréas endocrine. Les relations qui existent entre l'hyperplasie des îlots de Langerhans, l'obésité et le diabète sucré restent à établir, ainsi que les caractéristiques génétiques de chacun de ces éléments. L'intérêt de l'étude de ces animaux découle en grande partie de l'extrême hyperplasie du tissu pancréatique endocrine qui pourrait faciliter l'étude ultrastructurale de ce tissu, sa microdissection et sa transplantation, ainsi que sa culture sous forme d'organe ou de tissu. En outre, I'étude systématique de l'association des anomalies qui ont été constatées chez ces souris à piquants pourrait également orienter l'étude de l'association du diabète, de l'obésité et de l'hyperinsulinisme si souvent observée chez l'homme.

Zusammenfassung. Stachelmäuse (Acomys) sind kleine Nagetiere, die im östlichen Mittelmeerraum und in Afrika heimisch sind. Der Stamm Acomys Cahirinus, über den wir hier berichten, stammt aus Israel. Bemerkenswert ist bei diesem Stamm eine extreme kongenitale Hyperplasie der Langerhansschen Inseln, vor allem deren Beta-Zellen. Das Pankreas erwachsener Stachelmäuse besteht bis zu $15 \%$ aus Inseln, das neugeborener Tiere bis $25 \%$. Der Insulingehalt des Pankreas beträgt bis 100 i.E./g Feuchtgewicht. Bei freier Ernährung mit Laboratoriumskost werden ungefähr die Hälfte der Tiere fettsüchtig, während ca. 15\% einen Diabetes Mellitus-artigen Zustand entwickeln mit mäßiger Hyperglykämie, Glukosurie sowie, weniger häufig, Ketonurie und Gewichtsverlust, die zum Tod führen. Das Auftreten der diabetischen Stoffwechselstörung geht mit Degranulation und nachfolgender Glykogenose der Beta-Zellen der Langerhansschen Inseln einher. Außerdem fallen eine schwere Glycogen-Nephrose und Glycogen-Myocardose auf. Vorläufige, noch unvollständige Beobachtungen deuten auf eine Verdickung der Basalmembran der Kapillaren der Nierenglomerula und des endokrinen Pankreas hin. Die Zusammenhänge zwischen der Hyperplasie der Langerhansschen Inseln, der Fettsucht und der diabetischen Stoffwechselstörung sowie deren Vererbungsmodus sind noch unklar. Die Bedeutung der außerordentlich ausgeprägten Hyperplasiedes endokrinen Pankreas für die Forschung liegt darin, daß sie die elektronenoptische Untersuchung der Beta- 
Zellen sowie die Mikrodissektion des Inselgewebes für Transplantationen, Organ- und Gewebekulturen erleichtert. Ferner besteht die Möglichkeit, daß die systematische Untersuchung der Zusammenhänge der für diese Stachel- mäuse charakteristischen Anomalien wertvolle Hinweise für das Verständnis des häufigen Zusammentreffens von Diabetes, Fettsucht und Hyperinsulinaemie beim Menschen liefern wird.
During the past few years increasing attention has been paid to the well-known clinical association of obesity with diabetes mellitus and, in particular, to animal syndromes that present this association. A number of metabolic states associated with spontaneous hyperglycemia have been described in rodents and are chronologically recalled here. In several instances, the trait first described was obesity, with hyperglycemia recorded at a later date. Obesity as associated with a yellow color of the coat was first described by Cuńnot in $1905^{7}$; in 1950 , INGALLS and collaborators described the association of hyperglycemia and obesity in mice from the Jackson Memorial Laboratory, Bar Harbor, Maine ${ }^{\mathbf{1 4}}$, a syndrome which has been extensively studied by MAYER ${ }^{22}$; an obese strain of mice where hyperglycemia is frequently observed was described from New Zealand by Biecchowsky and Bielchow$\mathrm{SKY}^{4}$; while a clear-cut diabetic syndrome not associated with obesity was described in Chinese hamsters (Cricetulus griseus) by YERGANTAN ${ }^{37}$; hyperglycemia frequently associated with hyperlipemia in hereditary obesity in rats was reported by ZUCKER and ZUCKER ${ }^{39}$; and obesity and diabetes secondary to altered dietary intake in the sandrat (Psammomys obesus) has been described by SCHMIDT-NIELSEN and collaborators ${ }^{30}$. In this enumeration we have only mentioned those syndromes for which the existence of a hereditary component has been established. The sporadic occurrence, of spontaneous diabetes mellitus has of course been recorded in a large number of additional species, including dogs, cats and cattle.

We have been fortunate in fortutiously discovering the frequent occurrence of spontaneous hyperglycemia and glucosuria in Acomys Cahirinus* imported into Switzerland from Israel. According to WAHRMAN and ZAHAVI ${ }^{34}$, the mice of the genus Acomys form a well defined group of chiefly African and Eastern Mediterranean distribution. They are referred to as spiny mice because of the bristle-like modification of the hair which covers their back (Fig. 1). When raised in the laboratory, they frequently develop striking obesity and, in a significant proportion of these, a diabetic syndrome. Spiny mice, furthermore, exhibit the remarkable characteristic of a striking hypertrophy and hyperplasia of the islets of Langerhans ${ }^{10}$, 11 , which is already observed at birth. This association of obesity, diabetes mellitus, and congenital hyperplasia of the islets of Langerhans is so striking as to warrant, in our opinion, thorough and detailed analysis of the endo-

* In a preliminary communication ${ }^{10}$ we have referred to Acomys "Dimidiatus". This is a subgroup of Acomys "Cahirinus" and we have been advised to refer to the strain reported here by the more general name, since the subgroup determination is as yet uncertain. crine and metabolic traits involved, since their understanding might contribute to the understanding of the pathogenesis of diabetes and obesity, more generally. This is the first of a series of communications concerned with this syndrome in spiny mice.

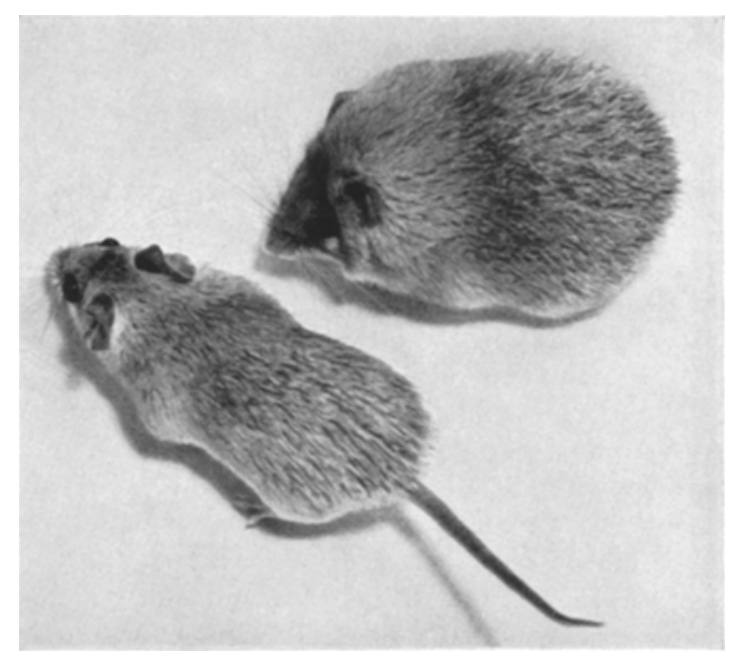

Fig. 1. Spiny mice (Acomys Cahirinus). The two animals shown are 8 months old. The one on the left (below) weighs $55 \mathrm{gm}$, the one on the right (top) $95 \mathrm{gm}$. Note the spiny, bristle-like back hair. The tails are dry scaly and very poorly vascularized. The obese animal has lost its tail by autoamputation

\section{Animals and Methods}

One of us (A.E.G.) had the opportunity of seeing two spiny mice kept as pets, one of which was remarkably obese. The animals were obtained as a gift and briefly investigated as part of a survey of animals with obesity. At death, the bladder urine of the obese mouse was positive for glucose and the histological appearance of the endocrine pancreas was most unusual. Accordingly, new animals of the same species were looked for and breeding couples of Acomys Cahirinus were obtained from the Department of Zoology in Basel, Switzerland, the original breeders of that stock having been obtained from Israel. The living conditions of these animals in the wild are mountainous and arid and the young leave their nest shortly after birth ${ }^{8}$. Their bristle-like back hair gives them the appearance of very small hedgehogs (Fig. 1); the tails are frequently auto-amputated. Their chromosomes have been studied by WAHRMAN and $Z_{A H A V I}{ }^{34}, 38$ and also, extensively, by MATrHEY ${ }^{21}$, because of the existence of chromosomal polymorphism. The gestation period of the animals raised in our laboratory is 39 days \pm 1 . This can be accurately measured since the female, which delivers litters varying between 1 and 4 , is immediately reimpregnated 
on the day of delivery. This permits an accurate estimation of the duration of the gestation and fetal age. As a rule, the litters were left with their mothers for a period of 4 weeks.

The animals were kept in an air-conditioned room at $23^{\circ} \mathrm{C}$ and $60 \%$ humidity, with automatic lighting kept at 14 hours per day. They were weighed at birth and weekly thereafter. At first, they were separated into two lots according to the diet given, one lot being fed ad libitum with standard pellets for rats and mice (Altromin R, Kunath, Aarau, Switzerland) the other lot receiving, in addition, a commercial mixture of seeds composed of $18 \%$ wheat, $13 \%$ dari, $10 \%$ corn, $7 \%$ hemp, $5 \%$ pumpkin, $5 \%$ oats, $3 \%$ millet, $27 \%$ sunflower and $12 \%$ of a mixture of grass seeds. While the animals were very young they seemed to grow faster on the diet supplemented with seeds, but the ultimate weight and incidence of obesity was not affected by the supplementation. Accordingly, we have selected as the standard diet the pellets supplemented with seeds.

Blood samples were obtained from the orbital sinus ${ }^{27}$ during very light ether anesthesia, using heparinized capillary tubes which were immediately centrifuged for 2 minutes, 20 microliters of serum being used for the determination of blood glucose, with the o-toluidine method according to HYväRINEN and NIKKш $\ddot{A}^{13}$ as modified by Mromod and FREY ${ }^{23}$. Nonfasted samples were obtained at 9 a.m., the animals having had free access to food during the preceding night, while fasting samples were obtained after 15 hours of food withdrawal. The glucosuria was measured qualitatively with glucose oxidase paper or quantitatively with the same o-toluidine method used for serum. Acetonuria was tested for qualitatively only with Acetest tablets (Ames). The collection of urine presents difficulties in this animal because of the small urine volume, rarely reaching $1 \mathrm{ml}$ in the normal state and not exceeding a few mls in the presence of diabetes. For the collection of urine, we have used the plastic metabolic cages designed by $G$. GAss and C. BuNTER and available commercially through Econo-Lab Division of Maryland Plastics, Inc., Federalsburg, Maryland.

Insulin-like activity of pancreas and serum was measured with the rat epididymal adipose tissue technique ${ }^{25}$, the extraction of the pancreas having been carried out with acid-ethanol according to SCOTT and FISHER ${ }^{31}$. Inhibition of this insulin-like activity in the presence of anti-insulin serum was tested for with serum obtained from guinea pigs immunized that pork insulin.

Body composition was studied on animals that were weighed, then killed without bleeding and kept at the temperature of solid carbon dioxide. After pul- verization in the frozen state, they were homogenized for 20 minutes in a known volume of distilled water in a Waring blendor. Weighed aliquots of approximately 10 grams each of the homogenate were then lyophilized for the determination of water content and the subsequent analyses were performed on these lyophilized samples. The total lipids were determined gravimetrically ${ }^{6}$ after extraction twice for 2 hours with $30 \mathrm{ml}$ chloroform-methanol $(2: 1)$ at $59^{\circ} \mathrm{C}$, followed by filtration through defatted filter paper and washing of the residue with solvent. The filtrate was taken to dryness at $40^{\circ} \mathrm{C}$ under a stream of air and the lipids taken up in petroleum ether and aliquots transferred to weighing flasks and dried. Duplicate values were averaged and the lipid content of the whole animal was calculated. The results obtained on at least 4 individual homogenate aliquots from one animal agreed with each other within less than $5 \%$. The results were expressed as total content as well as per cent of wet body weight. Nitrogen was determined after hydrolysis of dried homogenate in $30 \% \mathrm{KOH}$ at $100^{\circ} \mathrm{C}$ by a micro-Kejldahl procedure, using the ninhydrin reagent ${ }^{28}$, KCN being used at a concentration of 0.026 millimolar. The determinations were carried out in duplicate for each aliquot and the two values averaged. Total body nitrogen content was calculated and the total protein content obtained by multiplication by 6.25. The values for total body protein content calculated in this fashion from 4 individual samples of homogenate from one animal agreed with each other within less than $10 \%$.

For histological examination, the organs were fixed in formol, Bouin's or Carnoy's solutions. The staining procedures used were the following: hematoxylin-eosine, aldehyde-fuchsin according to GoMoRI ${ }^{9}$ as modified by WILsoN*, aldehyde-thionin as described by PAGET and modified by us ${ }^{12}$, periodic acid of SCHIFF, according to MaCMANUs ${ }^{20}$ and carmine according to BEST ${ }^{3}$. In a few instances silver impregnation according to JoNes ${ }^{15}$ and the metachromatic staining for insulin according to ScHIEBLER and SCHISSLER ${ }^{29}$ were also employed. In the presence of

Table 1. Body composition of one lean and three obese spiny mice (Acomys Cahirinus)

\begin{tabular}{|c|c|c|c|c|c|c|c|c|c|}
\hline \multirow{2}{*}{ Type, age, sex } & \multirow{2}{*}{$\begin{array}{l}\text { Wet weight } \\
\text { gm }\end{array}$} & \multicolumn{2}{|c|}{ Water content } & \multicolumn{2}{|c|}{ Fat content } & \multicolumn{2}{|c|}{ Protein content } & \multicolumn{2}{|c|}{ Residue } \\
\hline & & $\mathrm{gm}$ & $\%$ & $\mathrm{gm}$ & $\%$ & $\mathrm{gm}$ & $\%$ & $\mathrm{gm}$ & $\%$ \\
\hline $\begin{array}{l}\text { lean female } \\
7 \text { months }\end{array}$ & 33.2 & 19.0 & 57.5 & 6.4 & 19.3 & 5.2 & 15.7 & 2.5 & 7.5 \\
\hline $\begin{array}{l}\text { obese female } \\
16 \text { months }\end{array}$ & 88.7 & 34.6 & 39.0 & 38.6 & 43.5 & 9.4 & 10.6 & 6.1 & 6.9 \\
\hline $\begin{array}{l}\text { obese male } \\
14 \text { months }\end{array}$ & 90.6 & 40.8 & 45.0 & 31.7 & 35.0 & 10.5 & 11.6 & 7.6 & 8.4 \\
\hline obese male & 85.5 & 32.5 & 38.0 & 32.5 & 38.0 & 9.4 & 11.0 & 11.1 & 13.0 \\
\hline
\end{tabular}

* The Wilson modification has been made available to us by Prof. W. CReUtzFeld , Dept. of Medicine, University of Göttingen, Göttingen, Germany, as a personal communication. 
positive PAS staining the preparations were tested with amylase in order to establish whether the material was glyeogen or another polysaccharide. All sections were cut at a thickness of 5 microns unless silver impregnation was to be carried out, when the sections were cut at 2 microns. Finally, for dark-field microscopy, pancreas sections were cut at 20 microns thickness after freezing and mounted in glycerol. For electron microscopy pancreatic fragments were fixed in $2 \%$ osmium tetroxide buffered with S-collidine, then stained according to KARNOVSKY ${ }^{18}$.

The mass of the islets of Langerhans was estimated on serial sections of the pancreas. One section out of 20 was mounted and stained with aldehyde-thionin, then projected on paper of even thickness at a 25 -fold magnification. The outline of the endocrine and exocrine tissue was carefully drawn and the two portions cut out and weighed. The relative mass of the endocrine pancreatic tissue was so measured in one male, two female and one new-born Acomys Cahirinus, one albino Swiss mouse, one New Zealand obese mouse, one Bar Harbor obese mouse, and one yellow obese mouse.

\section{Results}

Individual spiny mice of the Acomys Cahirinus strain, raised in the laboratory under identical conditions, evidently vary greatly in the weight they achieve even though their nose to tail length did not so vary (Fig. 1, 2, 3). The differences between "lean" and "obese" individuals became apparent from approximately the second month of age onwards (Fig. 2 ). It is impossible to state definitively, at the present time, whether there are indeed two groups of animals, one lean and one obese, although a bimodal distribution

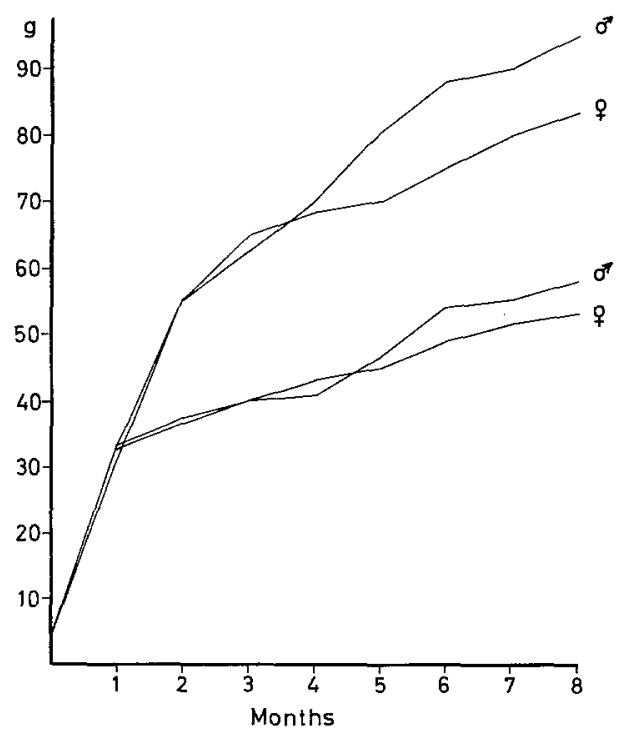

Fig. 2. Examples of evolution of body weight from birth to the adult state in two obese and two non-obese siblings. The male and the female in the obese and non-obese groups are from the same litter, but the obese and the non-obese animals are from two different litters

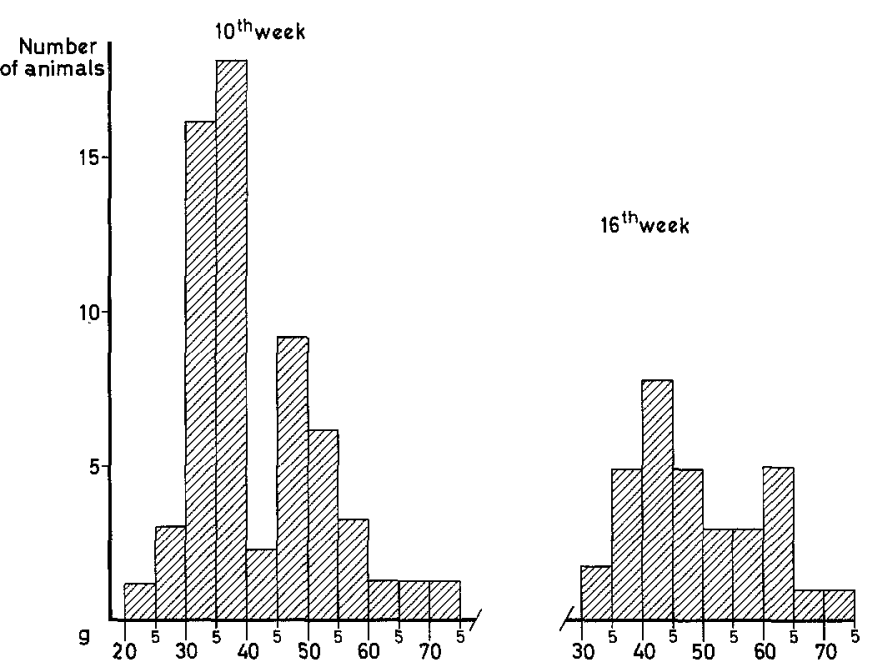

Fig. 3. Weight distribution among 65 spiny mice at 10 th and 16 th week of age. The number of animals at the 16 th week is less, since all pregnant females had to be excluded

is suggested (Fig. 3). However, a much larger population will have to be surveyed before this point can be established. Preliminary results with inbreeding suggest that obese and non-obese strains might be isolated from the mixed population now at our disposal. As obesity progressed in some, it was frequently accompanied by moderate hyperglycemia (Fig. 4) and

\section{ACOMYS $0^{\circ}$}

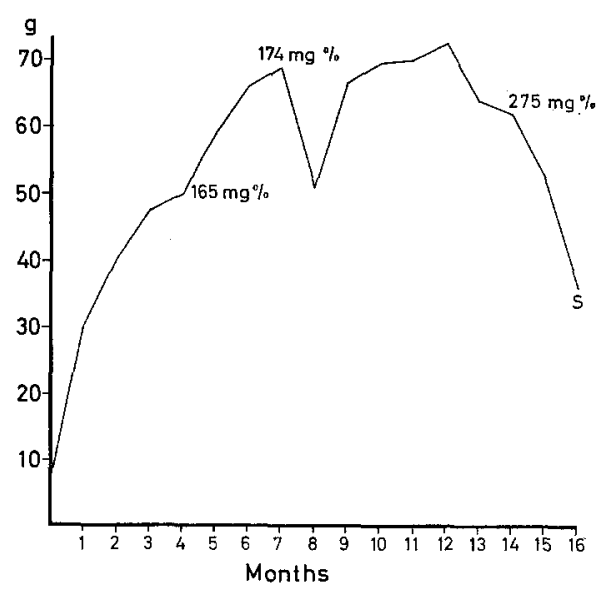

Fig. 4. Weight curve of a representative spiny mouse presenting obesity and, from the 5th month onward, mild hyperglycemia. The figures refer to fasting blood sugar values. The sudden weight dip at approximately 7 months of age was the result of isolation of the animal in a metabolic cage. Ketonuria was present from the 14 th month onward

glucosuria. At the beginning of weight loss, acetonuria became positive and death was not far off. Out of approximately 65 animals that have now been followed up to the age of 8 months or more, we can presently estimate that about one-half became clearly obese after the sixth month and that, of these, approximately one-quarter developed overt diabetes. Diabetes has been noted in the non-obese group, although less frequently. 
Because of the as yet small size and slow rate of growth of the colony, only a small group of animals has been sacrificed for a preliminary study of body composition: one female representative of those mice that do not become obese, and one female as well as two males of the obese group. The data presented in Table 1, clearly establish that the body composition of the animals that we have labelled as obese is indeed comparable to that of other strains of obese mice.

The most striking histological observation made in the spiny mice concerns the endocrine pancreas. From birth and throughout life these animals exhibit an extraordinarily large number of islets of Langerhans, many of these being very large in size (Figs. 5 and 6 ). Whereas some degree of hyperplasia and hypertrophy of the islets of Langerhans is characteristic of other strains of mice with obesity, the degree of the hyperplasia seen in the spiny mice is, to our knowledge, unmatched, with the possible exception of the hybrid mice with mild diabetes and co-existing pancreatic beta cell tumors described by JoNEs ${ }^{16}$ and studied more extensively by LIKE and collaborators ${ }^{19}$. The outline shown in the upper portion of Fig. 5 represents a section through only part of the pancreas of an obese spiny mouse, which exhibited at death (after an overnight fast) a blood glucose level of $165 \mathrm{mg} \%$. The insulin content of another portion of the same pancreas was 28 units per gram, expressed in terms of insulin-like activity, all of which was suppressible in the presence of anti-insulin serum. The highest level of insulin content measured in an obese adult animal
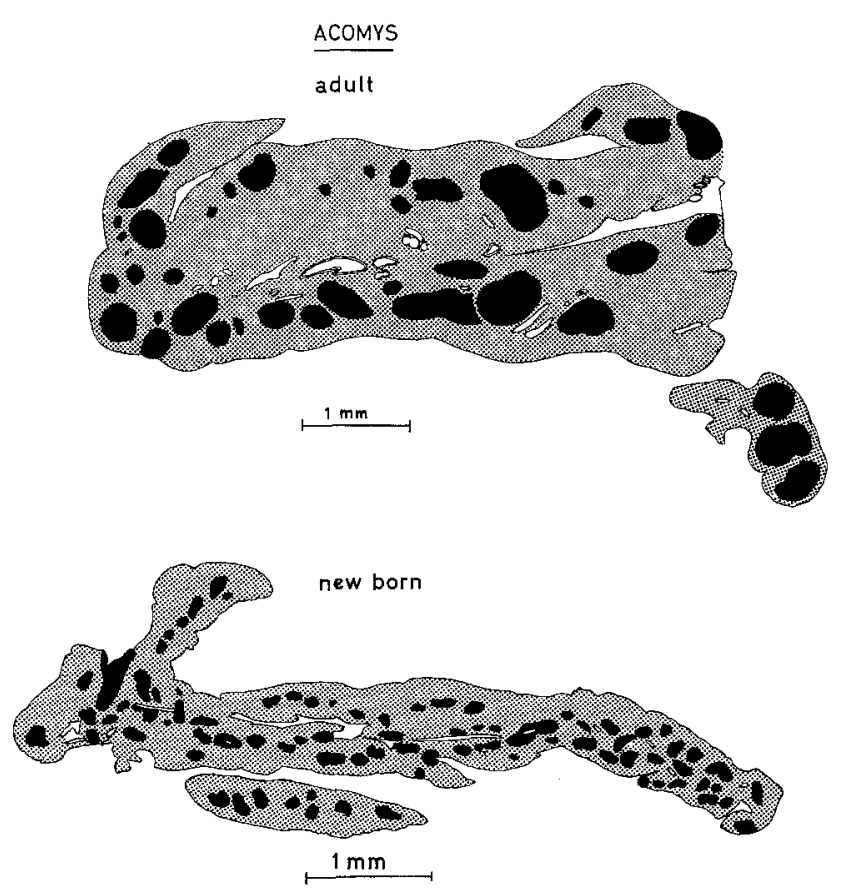

Fig. 5. Accurate graphic representation of a slice through the tail of the pancreas of an obese, adult, non-diabetic spiny mouse (upper drawing) and through the entire pancreas of a newborn spiny mouse (lower drawing). The areas drawn in black are the islets of Langerhans without hyperglycemia was 100 units per gram, but a systematic study of pancreatic insulin content will be presented only when the colony has grown to a size sufficient for systematic autopsies at specified ages.

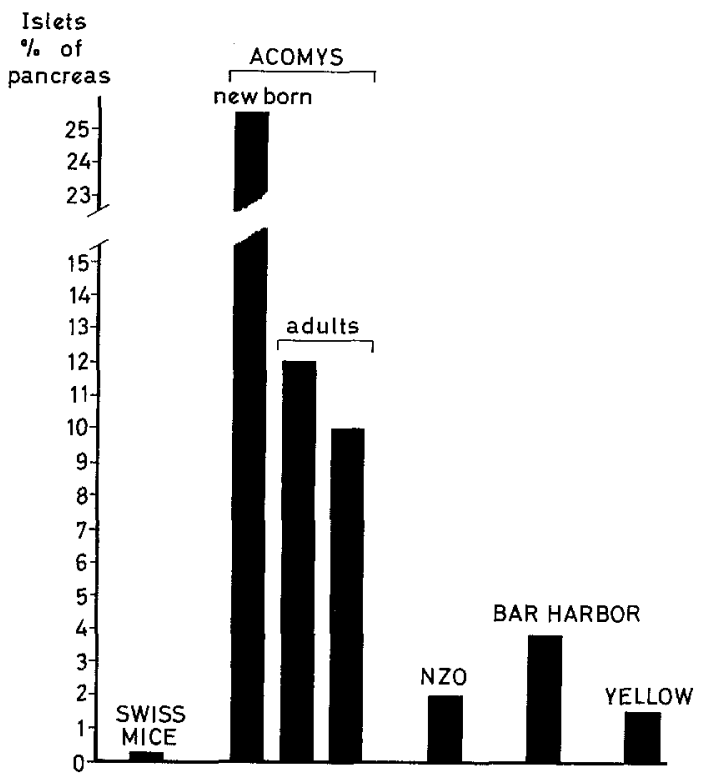

Fig. 6. Percentage of panereatic mass occupied by the islets of Langerhans in several strains of mice. NZO = New Zealand Obese; Bar Harbor = North

American strain of obese-hyperglycemic mice; yellow = yellow obese

The islets of Langerhans contain a large number of beta cells which are well granulated in both obese and non-obese, non-diabetic animals (Fig. 8). The alpha cells are usually distributed in small numbers throughout the islets, although occasional instances of separate islets consisting of pure beta cells and of pure alpha cells have been recorded.

We have also begun the study of the pancreas of spiny mice using the electron microscope and an illustration of these studies is shown in Fig. 7 which demonstrates two well-granulated beta cells in close proximity to a capillary. This particular sample was obtained from a mouse, aged 4 months and just beginning to show glucosuria. It is of interest that the basement membrane of the endothelium appears thickened and that the endothelium of the capillaries in this animal simultaneously presented pinocytosis vesicles and endothelial pores.

When the pancreas was obtained from animals presenting moderate glucosuria without acetonuria, the appearance of the islets was usually that demonstrated in Fig. 9, rather complete degranulation having occured. This degranulation was demonstrated with aldehyde-fuch $\sin ^{9}$, aldehyde-thionin (22, Fig. 9), and with the metachromatic insulin staining with pseudoisocyanine ${ }^{29}$. The pancreas obtained from animals clearly in the catabolic phase of their syndrome, with glucosuria and acetonuria, exhibited further, and dramatic changes in the islets of Langerhans, as shown in 
Figs. 10 and 11. The beta cells are now vacuolated and exhibit hypertrophic degeneration and, when the PAS stain was applied, they were shown to be filled with PAS-positive material which disappeared after amylase treatment and thus may be assumed to be glycogen. Only the sparse alpha cells retained their normal confirmed by the glycogen nephrosis which was seen in all diabetic animals (Fig. 12). The PAS-positive material disappeared completely with amylase. The cardiac muscle of diabetic animals frequently showed a glycogenic myocardosis with focal areas of necrosis, swelling and degeneration of the muscular fibers, and



Fig. 7. Electron micrograph of part of an islet of Langerhans obtained from an obese, adult, spiny mouse with very early hyperglycemia. Portions of two Beta cells (B) are shown adjoining a capillary. Note the simultaneous presence of pinocytosis vesicles (Pv) and of endothelial pores (P). The endothelial basement membrane (BM) appears thickened. $\mathbf{E}=$ endothelial cells. $\mathrm{L}=$ capillary lumen. $\mathrm{M}=$ mitochondria in beta cells. $\beta=$ beta granules. EnIargement: $22.400 \mathrm{x}$

appearance. Figs. 8, 9, 10 and 11 together illustrate the dynamic aspects of the pancreatic changes that accompany the development of the spontaneous diabetic syndrome in the obese spiny mice.

Additional histological alterations which are of interest have been observed in organs other than the pancreas. The hyperglycemia at death was strikingly abnormalities of the nuclei (Fig. 13). Some areas appearedematous and contain a necrobiotic material associated with invasion by leukocytes. This glycogenic myocardosis resembles that described recently as focal, tumoriform muscular degenerations in human diabetics by ANGERvall and STENER ${ }^{1}$. During the obese non-diabetic phase hepatic glycogen often appears 

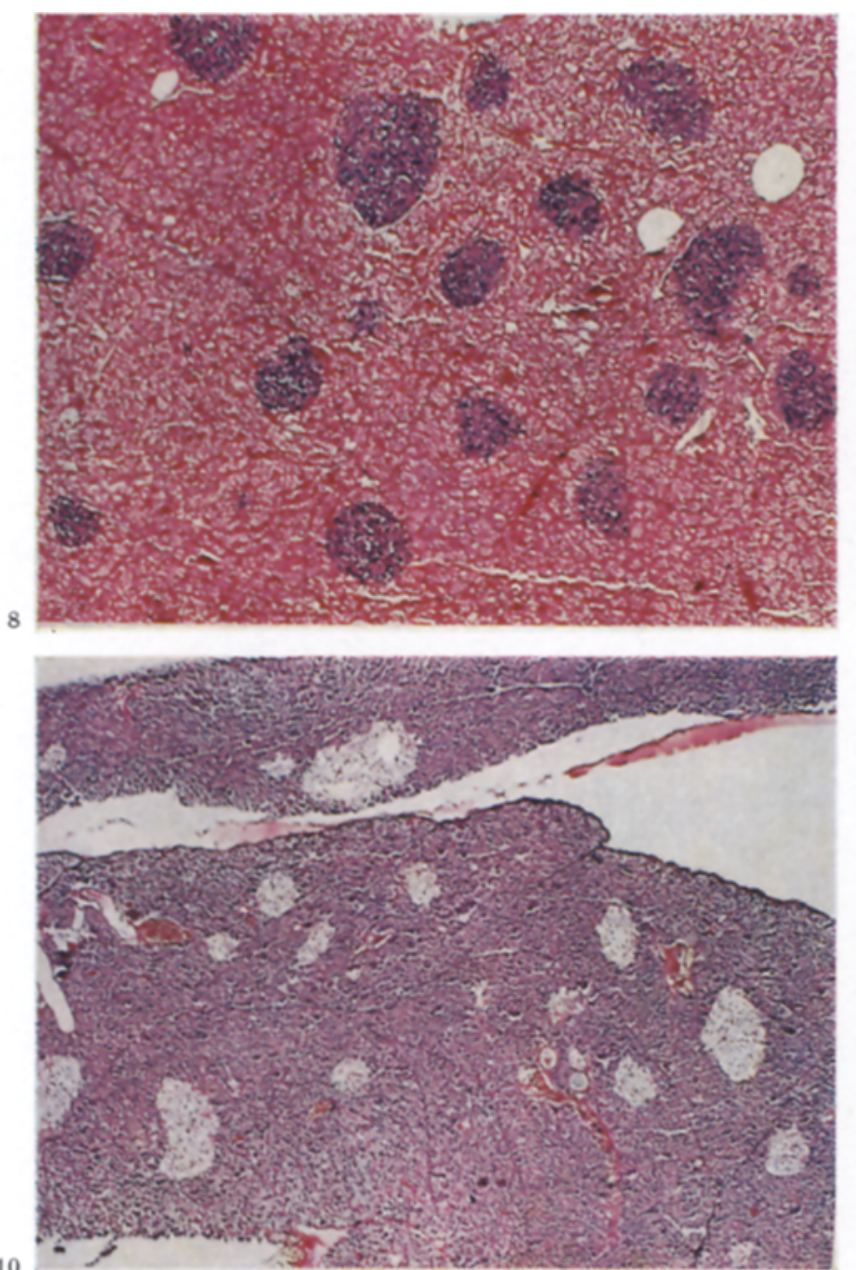

10

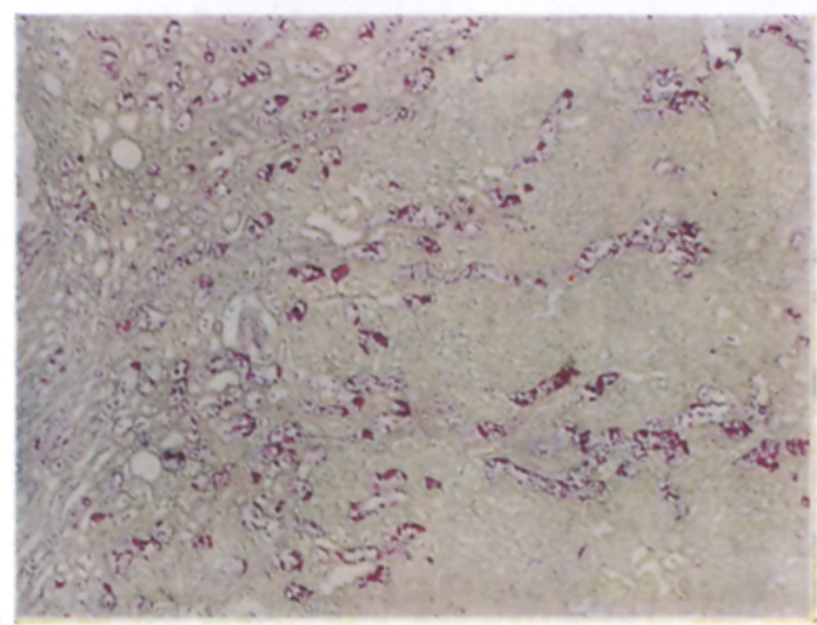

Fig. 8. Increase in size and number of islets of Langerhans of an aduit, moderately obese, non-diabetic spiny mouse. The beta granules are blue. Aldehyde-thionin stain. Enlargement: $50 \mathrm{x}$

Fig. 10. Vacuolization and degeneration of the beta cells of the islets of Langerhans in a diabetic spiny mouse during the severe, catabolic phase of diabetes. Aldehyde-thionin stain. Enlargement: $50 \mathrm{x}$

Fig. 12. Glyeogenic nephrosis in a diabetic spiny mouse. PAS stain. En largement: $50 \mathrm{x}$
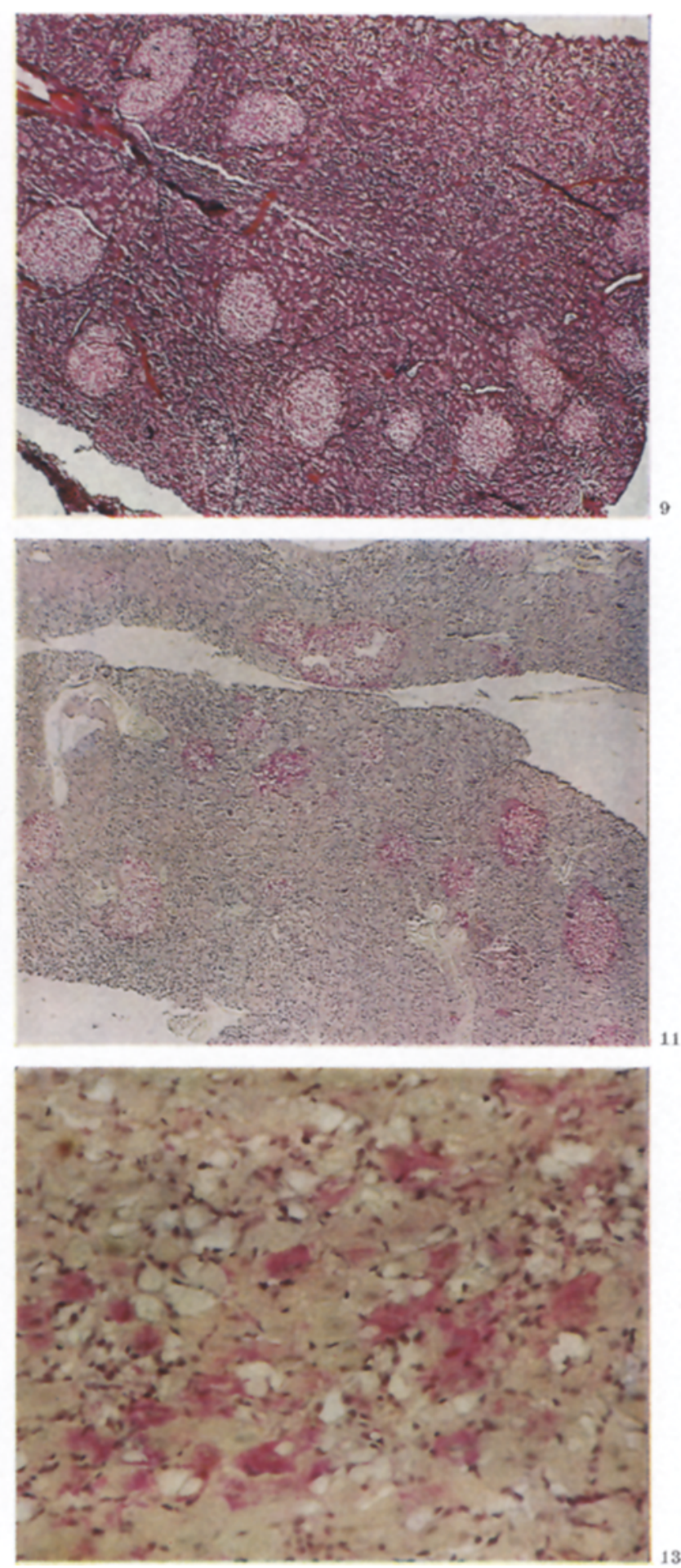

Fig. 9. Degranulation of the beta cells of the islets of Langerhans in a marlsedIy obese, but as yet non-diabetic spiny mouse. Note the disappearance of the blue granules. Aldehyde-thionin stain. Enlargement: $50 \mathrm{x}$

Fig. 11. Neighbouring slide to that shown in Fig. 10, stained with PAS. Note that the vacuolated cells are filled with PAS positive material. Upon digestion with amylase this moterial disappeared. Enlargement: $50 \mathrm{x}$

Fig. 13. Glycogenic myocardosis in a diabetic spiny mouse. Note the swelling of the myocardial fibers, the swelling of the nuclei and the focal areas of necrosis. PAS stain. Enlargement: $250 \mathrm{x}$ 
to be increased histologically, while hepatic glycogen is strikingly diminished during the catabolic phase of diabetes associated with ketonuria. Finally, silver staining according to JoN $\mathrm{ES}^{15}$, clearly demonstrates the existence of some thickening of the glomerular basement membranes. This would appear to be a relatively early development in these spiny mice, the tissue shown in Fig. 14 having been obtained from an obese but non-diabetic animal.

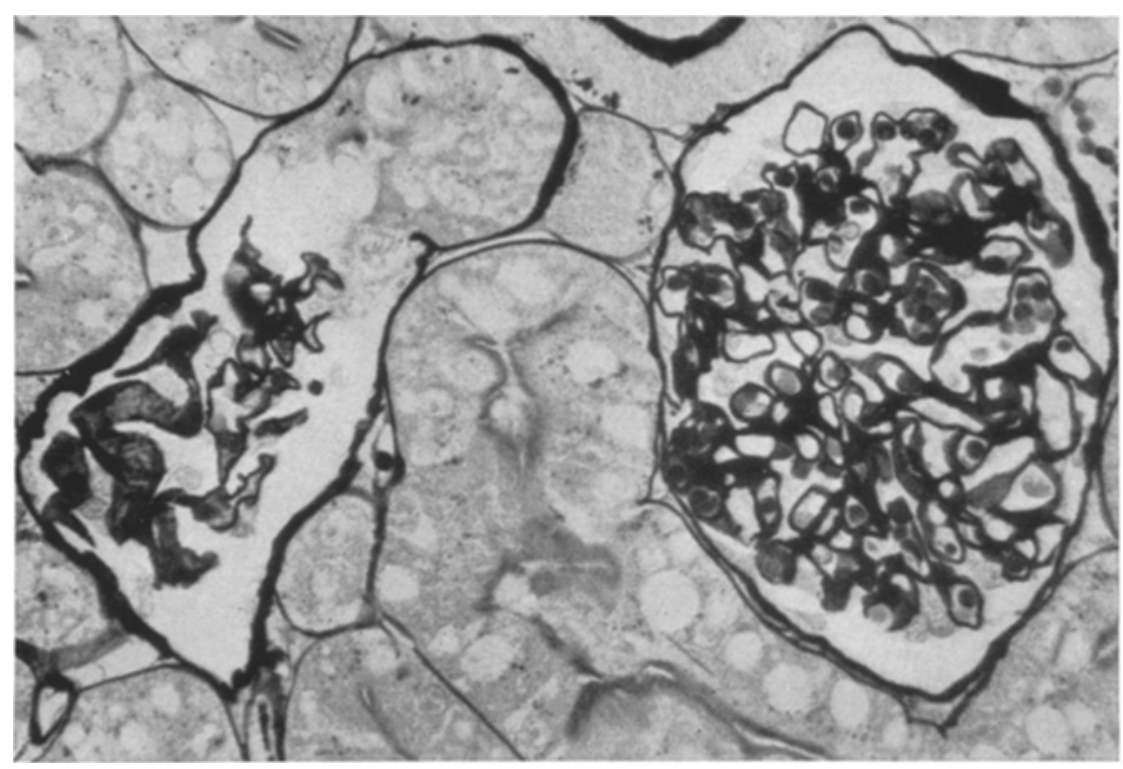

Fig. 14. Silver impreguation of a thin silee (2 mierons) of the kidney of an obese spiny mouse. Note the moderately but definitely thickened glomerular basement membrane. Stained according to Jones. Enlargement: $400 \mathrm{x}$

The hyperplasia of the islets of Langerhans is unusual in its degree, since in most mammals the islets do not account for more than approximately 1 per cent of the mass of pancreatic tissue. In adult spiny mice this percentage was increased to as high as 15 per cent and in the newborn to as high as 25 per cent of the pancreatic mass. The hyperplasia seemed to be more striking in the case of the beta cells of the islets than in the case of the alpha cells, although alpha cells were seen in most individual islets studied. Indeed, the islet tissue appeared quite normal in the non-diabetic animals, and even the largest islets were well vascularized and did not exhibit signs of necrosis, degeneration or cavitation as seen, in particular, in the hybrid mice described by JoNEs ${ }^{16}$. In the latter, the islets were thought to be adenomatous, whereas in the spiny mice nothing suggests a neoplastic modification of the endocrine pancreatic tissue.

The hyperplasia is unusual in that it is clearly congenital. It has been observed in all animals of the strain, whether obese or non-obese, whether diabetic or non-diabetic, and in particular also in the newborn offspring of mothers without hyperglycemia at birth. It is therefore unlikely that the hyperplasia is secondary to the laboratory environment to which these ani-

As yet the histological examination of the pituitary, thyroid and lymphatic organs has not suggested the existence of striking anomalies. The relatively greater size and maturity of the posterior pituitary in young spiny mice has been commented on by FLÜCKIGER and OPERSCHALL ${ }^{8}$ and related to the early need to preserve water in these animals, which live in an environment of semi-desert and early leave their nests. The glomerular region of the adrenal cortex and the interstitial cells of the testes exhibited an unusual accumulation of a PAS-positive and lipoid material which is only mentioned here in preliminary fashion and will be investigated more extensively in the future.

\section{Discussion}

The Cahirinus strain of Acomys or spiny mice available to us, appears to warrant systematic study on the basis of the data, primarily histologicaJ, presented in this study. The interesting features of the strain are firstly, the hyperplasia of the islets of Langerhans; secondly, the frequent occurrence of a diabetic state; and thirdly, the high incidence of obesity. mals have become accustomed over many generations, although a systematic study with different nutritional regimes will be required to establish this fact. It is as yet unknown whether the islet hyperplasia is characteristic only of the strain obtained and raised in our laboratory, or whether it is a general characteristic of Acomys Cahirinus, or more generally still, of all spiny mice. Studies on spiny mice caught in the wild in various regions of the Eastern Mediterranean and Africa should prove of considerable interest.

The occurrence of such a striking hyperplasia of the islets of Langerhans should greatly facilitate the ultrastructural study with the electron microscope of the fetal and postnatal development of the endocrine cells of the pancreas and also, since diabetes develops spontaneously in many of the animals, of the ultrastructural changes that accompany the onset of the disorder. Furthermore, the extraordinarily high percentage of endocrine cells in the pancreatic tissue of these spiny mice, occurring at/or before birth, should greatily facilitate culture and transplantation studies of endocrine pancreatic tissue. Finally, it will be of considerable interest to explore whether the hyper- 
trophy is related to a difficulty in the release of insulin, or whether it is rather the expression of a hyperplasia secondary to a state of decreased sensitivity to insulin as a result of some type of antagonism to insulin, which might be related to the pituitary or other endocrine structures. As of the present, all that can be said is that the hyperplasia is associated with a striking increase in the insulin content of the pancreas and that as yet preliminary measurements of insulin-like activity of serum have suggested the presence of normal or high, not of low, serum values.

A diabetes mellitus-like state developed in approximately 15 per cent of the animals which reached 8 months of age or more. The appearance of the diabetic state was associated with striking alterations in the beta cells of the islets of Langerhans which have been illustrated in Figs. 8-11. The metabolic information available is as yet preliminary but suggests that hyperglycemia remained moderate, around $300 \mathrm{mg} /$ $100 \mathrm{ml}$, even when ketonuria and weight loss supervened. It is therefore quite possible that a relatively low renal threshhold for glucose is a feature of the syndrome in these animals which, furthermore, appear to be remarkably efficient in their reabsorption of water since urine glucose levels as high as 16 per cent have been observed. The existence of hyperglycemia with glucosuria for some time before sacrifice was corroborated in several animals by the severe glycogen nephrosis, while the basement membrane changes observed both in the kidney (Fig. 14) and, with the electron microscope, in the pancreas (Fig. 7) suggest that these animals may provide a valuable tool in the exploration of the pathogenesis of the basement membrane anomalies in diabetes. The myocardial alteration (Fig. 13) is similar to that described by ANGERvall and STENER ${ }^{1}$ as already pointed out. The occurrence of the diabetes-like state in association with, or in spite of, massive hyperplasia of insulin-producing cells, argues in favour of the existence of a state of resistance to insulin in these animals. This and many other metabolic features of the syndrome remain to be established, as soon as the colony will have grown to a size sufficient for systematic sacrifice of animals at various stages of the development of the disorder. A major disadvantage of the animal in this respect is that of the impossibility of bleeding from any site other than the orbital sinus, a procedure which is difficult in this animal without anesthesia.

An important aspect of further studies will be that of exploring whether the development of a diabetes-like state in these animals is limited to the strain which we are studying, and whether, within this strain, its incidence may be increased by inbreeding, or whether it occurs in different types of spiny mice observed in the wild.

Obesity developed in at least half of the approximately 100 animals which have been observed so far for over 4 months or longer. The percentage may increase with prolonged observation and, indeed, it is still possible that both the lean and the obese individuals are part of a continuous distribution curve, although some individuals have been observed to remain clearly lean for as long as they have been followed, i.e., maximally one year. When compared with Bar Harbor obese mice, yellow obese mice, or New Zealand obese mice, the distribution of the obese adipose tissue in spiny mice differs in that it is primarily subcutaneous, very much less intra-abdominal. The overall degree of the obesity, however, as judged by body composition studies, is comparable to that found in yellow obese mice ${ }^{35},{ }^{36}$, in the New Zealand strain of obese mice ${ }^{6}, 4$ and in mice made hyperphagic by the injection of goldthioglucose ${ }^{2}$, while somewhat inferior to that seen in the Bar Harbor, North American strain of obese hyperglycemic mice ${ }^{2}$. Since the lean animals are better breeders than the obese animals, we have as yet sacrificed only one lean spiny mouse for the purpose of total body composition studies. While the results obtained are quite similar to those found in lean animals of other strains of mice ${ }^{35}$, 2,33 this finding, of course, is to be considered preliminary only. Also, it remains to be seen whether obesity in these animals is limited to laboratory raised strains or whether it is also encountered in the wild.

The association of obesity with hyperinsulinism and a tendency toward hyperglycemia and diabetes has been frequently commented upon in recent times, both in animals ${ }^{5,26,32}$ and in $\operatorname{man}^{17,24}$. The interrelationships of hyperplasia of the islets of Langerhans, of obesity, and of diabetes mellitus in these spiny mice will be studied in considerable detail and may provide important information with regard to other syndromes of importance to animal, and perhaps human patho$\log y$.

Finally, it should be pointed out that this laboratory's decision to engage in a long-range and systematic study of the syndrome described here in spiny mice is part of a general interest in any form of spontaneous diabetes and/or obesity in animals. It is the opinion of the authors that the careful analysis of spontaneous, hereditary forms of diabetes and obesity in experimental animals is likely to provide one of the strongest tools for the unravelling of probably complex pathogenetic events in these so widely prevalent diseases in man. This very prevalence is in itself an obstacle to pathogenetic investigations since the syndromes may well be the similar end-result of a number of pathogenetic mechanisms. In experimental animals, where genetic and tissue studies can be pursued more easily and more rapidly, clues may be obtained which may prove of help in the study of the human syndromes as well.

\section{Acknowledgements}

The studies with the electron microscope have been carrjed out in collaboration with the Centre de pathologie ultrastructurale (Dr. SImon and Prof. E. Rutishauser) of the Geneva University Hospital. The authors are also greatly indebted to $H$. BAUMANN, from the Dopartment of Histology, for help with the colour photography. 


\section{References}

${ }^{1}$ Angervali, L., and B. Stener: Tumoriform focal muscular degeneration in two diabetic patients. Diabetologia 1, 39-42 (1965).

2 Bates, M.W., S.F. NaUSs, N.C. HagmanN and J. MAYER: Fat metabolism in three forms of experimental obesity: body composition. Am. J. Physiol. $180,301-303(1955)$.

3 Best, K. cited by Romers, B. : Mikroskopische Technik, Leibniz Verlag München 1948, p. 258: Ausführung der Carminfärbung nach Best.

4 Biflschowsky, M., and F. Btelschowsky: A new strain of mice with hereditary obesity. Proc. Univ. Otago Med. Sch. 31, 29-31 (1953).

${ }^{5}$ Christophe, J.: Le syndrome récessif obésité - hyperglycémie de la souris. Ses relations possibles avec le diabète gras humain. Bull. Acad. Méd. Belg. 5, $309-390(1965)$.

"Crofford, O.B., and C.K. Davis, Jr.: Growth characteristics, glucose tolerance and insulin sensitivity of New Zealand obese mice. Metab. Clin. Exp. 14, 271-280 (1965).

${ }^{7}$ CUÉNOT, L.: Los races pures et leurs combinaisons chez les souris. Arch. Zool. Exp. Gen. 3, 123-232 (1905).

${ }^{8}$ Flǘchiger, E., and P. OPERSChall: Die funktionelle Reife der Neurohypophyse bei neonaten Nestflüchtern und Nesthockern. Rev. Suisse Zool. 69, $297-301$ (1962).

${ }^{9}$ Gomori, G.: A new stain for elastic tissue. Am. J. Clin. Pathol. 20, 665 (1950).

10 Gonet, A.E., J. Mougis and A.E. Renold : Hyperplasia and hypertrophy of the islets of Langerhans, obesity and diabetes mellitus in the mouse Acomys Dimidiatus. Acta Endocrinol. Suppl. 100, 135 (1965).

11 - Polynésie et macronésie spontanées des îlots de Langerhans, souvent associées à l'obésité, chez Acomys Cahirinus, Résumés de la première réunion de l'Association Européenne pour l'étude du diabète. Montecatini-Terme (1965), Diabetologia 1, 144 (1965).

12 -, and A.E. RENOLD: Homografting of fetal rat pancreas. Diabetologia 1, 91-96 (1965).

13 HYvärinen, A. and E.A. NtKkn̈̈: Specific determination of blood glucose with o-toluidine. Clin. Chim. Acta 7, 140-148 (1962).

14 Ingalls, A.M., M. M. Dickie and G.D. SNell: Obese, new mutation in the house mouse. J. Heredity 41, $317-318(1950)$.

15 Jones, D.B.: Nephrotic Glomerulonephritis Am. J. Path. 33, 313-330 (1957).

16 JonEs, E.E.: Spontaneous hyperplasias of the pancreatic islets associated with glucosuria in hybrid mice. A preliminary report. Wenner-Gren Symposium on Islet Structure and Function. Pergamon Press, London, p. $189-191$ (1964).

17 KARAM, J.H., G.M. GRODSKY and P.H. ForshaM: Excessive insulin response to glucose in obese sub. jects as measured by immunochemical assay. Diabetes 12, 197-204 (1963).

18 KARNovsky, M.J.: A simple method for staining with lead at high $\mathrm{pH}$ in electron microscopy. J. Biophys. Biochem. Cytol. 11, 729-732 (1961).

${ }^{19}$ LiKe, A.A., J. STEINke, E.E. Jones and G.F. CAHILL, Jr. : Pancreatic studies in mice with spontaneous diabetes mellitus. Am. J. Pathol. 46, 621-644 (1965).

20 MacManus, J.F.A.: Histological demonstration of mucin after periodic acid. Nature 158, 202 (1946).

21 Matwhey, R.: Polymorphisme chromosomique intraspécifique et intraindividuel chez Acomys Minous Bate (Mammalia:Rodentia: Muridae). Etude cytolo- gique des hybrides Acomys ${ }^{\star} \times$ Acomys Cahirinus 0 . Le mécanisme des fusions centriques, Chromosoma 14, $468-497(1963)$.

22 Mayer, J.: The obese hyperglycemic syndrome of mice as an example of "metabolic" obesity. Am. J. Clin. Nutr. 8, 712-718 (1960).

${ }^{33}$ Michod, J., and J. Frey : Méthode rapide et spécifique pour le dosage de la glycémie par l'o-toluidine pour les urgences. Bull. Soc. Suisse chim. clin. 7, 54 (1963).

24 Rabinowitz, D., and K.L. ZierLer: Forearm metabolism in obesity and its response to intra-arterial insulin : evidence for adaptive hyperinsulinism. Lancet 2, $690-692$ (1961).

25 Renold, A.E., D.B. Martin, Y.M. Dagenais, J. Steinke, R.J. Nickerson and M.C. Sheps: Measurement of small quantities of insulin-like activity using rat adipose tissue. I. A proposed procedure. J. Clin. Invest. 39, 1487-1498 (1960).

26 - , and D.A.B. Young: Possible chemical defects in diabetes mellitus in man and hereditary diabetes mellitus in animals. Exc. Med. Intern. Congr. Ser. 83 (Proc. 2nd Internat. Congress Endocrinology p. 883 $-887(1965)$.

${ }^{27}$ Riley, V.: Adaptation of orbital bleeding technic to rapid serial blood studies. Proc. Soc. Exp. Biol. Med. 104, 751-754 (1961).

28 Rosen, H., C.W. Berard and S.M. Levenson: A simplified procedure for automatic amino acid analysis. Anal. Biochem. 4, 213-221 (1962).

29 Schiebler, T.H., and S. SchiessLer: Über den Nachweis von Insulin mit meta-chromatisch reagierenden Pseudoisocyaninen. Histochemie 1, 445-465 (1959).

30 SchmidT-NiELSEN, K., H. B. Haines and D. B. HackEL: Diabetes mellitus in the sandrat induced by standard laboratory diets. Science 143, $689-690$ (1964).

31 Scotr, D.A., and A.M. Fisher: Studies on the pan. creas and liver of normal and of zine-fed eats. Am. J. Physiol. 121, 253-260 (1938).

32 SNEYD, J.G.T.: Pancreatic and serum insulin in the New Zealand strain of obese mice. J. Endocrinol. 28, $163-172$ (1964)

33 Subrahmavyam, K.: Metabolism in the New Zealand strain of obese mice. Biochem. J. 76, 548-556 (1960).

${ }^{34}$ WAHRMAN, J., and A. ZAHAVI: Intra-generic difference in chromosome numbers of spiny mice (Rodentia: Murinae). Bull. Res. Council Israel 3, 265 (1953).

${ }^{35}$ WeITze, M.: Hereditary adiposity in mice and the cause of this anomaly. Store Nordiske Videnskabs. boghandel (1940).

${ }^{36}$ WOLFF, G.L.: Body composition and coat color correlation in different phenotypes of "viable yellow" mice. Science 147, 1145-1147 (1965).

37 YerganIaN, G.: Spontaneous diabetes mellitus in the Chinese hamster, Cricetulus griseus. IV. Genetic aspects. Ciba Foundation. Colloquia on Endocrinology, 15, Aetiology of Diabetes Mellitus and its Complications. Cameron, M.P., and M. O'Connor, eds., Churehill, J. and A. Ltd., London, p. 25-48 (1964).

${ }^{38} \mathrm{Z}_{\mathrm{AHAVI}}$, A., and J. WAHRMAN : Chromosome races in the genus Acomys (Rodentia: Murinae). Bull. Res. Council Israel 55 B, 316 (1956).

${ }^{39}$ ZUCKER, T.F., and L.M. ZuCKER: Hereditary obesity in the rat associated with high serum fat and cholesterol. Proc. Soc. Exp. Biol. Med. 110, 165-171 (1962).

Dr. A. E. Gonet

Institut de Biochimie Clinique

Université de Genève

Sentier de la Roseraie

Genève/Suisse 